\title{
Granica nieruchomości a zmiana biegu rzeki granicznej w świetle Statutów Kazimierza Wielkiego
}

\section{Grenzen der Liegenschaften und Änderung des Flusslaufes angesichts der Statuten von Kasimir dem Großen}

1. Wprowadzenie. 2. Różnice między poszczególnymi redakcjami i wnioski płynące z rozbieżności dostrzeżonych w dotychczasowych badaniach. 3. Oznaczanie granicy dóbr ziemskich. 4. Przepis stanowiący o granicy biegnącej korytem rzeki: 4.1. Uzasadnienie ingerencji ustawodawcy; 4.2. Postanowienie, iż rzeka może stanowić granicę: 4.2.1. Przyczyny zmiany koryta i możliwe reakcje ustawodawcy, 4.2.2. Rozwiązania przyjęte w poszczególnych redakcjach Statutów Kazimierza Wielkiego (๘ Konsekwencje naturalnej zmiany biegu rzeki, a Konsekwencje zmiany koryta w wyniku działalności ludzkiej, - Nakaz przywrócenia stanu poprzedniego), 4.2.3. Prawo dostępu do wody i powstające $w$ związku $z$ nim wątpliwości. 5. Podsumowanie.

1. Einleitung. 2. Unterschiede zwischen den einzelnen Herausgaben und Schlussfolgerungen aus den in bisherigen Untersuchungen bemerkten Unterschieden. 3. Markierung der Grenzen von Landgütern. 4. Vorschrift über den Verlauf der Grenze entlang des Flussbettes: 4.1. Begründung für Einmischung des Gesetzgebers; 4.2. Beschluss, dass ein Fluss eine Grenze bilden kann: 4.2.1. Ursachen der Umbettung und mögliche Reaktionen des Gesetzgebers, 4.2.2. Beschlüsse in einzelnen Ausgaben der Statuten von Kasimir dem Großen ( Konsequenzen der natürlichen Änderung des Flusslaufes, Konsequenzen der künstlichen Umbettung des Flusslaufes, Befehl zur Wiederherstellung des vorherigen Zustandes), 4.2.3. Wasserzugangsrechte und im Zusammenhang damit entstehende Bedenken. 5. Resümee.

1. Datowane na połowę XIV w. Statuty Kazimierza Wielkiego nie zachowały się w redakcji pierwotnej ${ }^{1}$. Ich szerokie zastosowanie w praktyce skutkowało pojawieniem się licznych kopii poddawanych w procesie przepisywania przez skrybów rozmaitym, zamierzonym lub przypadkowym przeróbkom.

\footnotetext{
' W XIX i XX w. Statuty Kazimierza Wielkiego stanowily przedmiot bardzo intensywnych badań (zob. bogate zestawienie literatury Studiów z Dziejów Państwa i Prawa Polskiego, t. III); niestety nie została $w$ nich podjęta kwestia poruszona $w$ niniejszej publikacji.
} 
2. Zachowane redakcje, pochodzące $\mathrm{z} X \mathrm{XV}$ i XVI stuleci, sporządzone zostały w kilku językach, mianowicie lacińskim, polskim i ruskim. Chociaż wszystkie redakcje zawierają kopie tych samych statutów, to jednak o identyczności - nie tylko poszczególnych postanowień - mówić nie można. Kopiści popelniali omyłki lub wprowadzali zmiany polegające na opuszczaniu kilku czy kilkunastu artykułów, uzupełniali tekst postanowieniami nie znanymi innym redakcjom, łączyli kilka artykułów w jeden lub odwrotnie: rozbijali jeden artykuł na kilka².

Dotychczas nie została podjęta pełna analiza różnic $w$ poszczególnych redakcjach Statutów Kazimierza Wielkiego, niemniej dokonane wyrywkowe badania sugerują, że oczekiwać można interesujących wyników. Okazuje się bowiem, że kopiści nie mieli zahamowań przed dostosowaniem odpowiednich przepisów do zmian zachodzących $w$ sądowej praktyce. W ten sposób ewoluowały w poszczególnych redakcjach przepisy dotyczące nagany i oczyszczenia szlachectwa ${ }^{3}$. Jak dotąd nikt jeszcze nie zastanawial się nad tym, czy był to przypadek jednostkowy, czy też podobna praktyka występowała na szerszą skalę.

3. W średniowiecznej Polsce spory graniczne regulowane były przez zwyczaj, który przewidywał określoną procedurę wyznaczania granic ${ }^{4}$. Gwarantowal także właścicielowi prawo oznaczenia własności widocznymi znakamis. Mogły być do tego wykorzystane - w określonym trybie - naturalne elementy krajobrazu: rzeka, charakterystyczne drzewo, glaz czy pagórek. W razie ich braku posługiwano się sztucznymi konstrukcjami, jak kopce czy słupy ${ }^{6}$. Nierzadko sztuczne znaki sytuowano na obiektach naturalnych (np. ciosna na drzewach).

Zwyczaj gwarantowal też prawną ochronę tych znaków, uznając ich naruszenie za przestępstwo ${ }^{7}$. Z zasady - co należy podkreślić - kwestie związane $\mathrm{z}$ granicami, aż do upadku Rzeczpospolitej rozstrzygało prawo zwyczajowe ${ }^{8}$.

${ }^{2}$ Znamy redakcje, w których połączono zwód wielkopolski i małopolski, a także takie, w których zawarto normy z jednej tylko prowincji; por. St. Roman, Geneza Statutów Kazimierza Wielkiego, Kraków 1961.

${ }^{3}$ Por. J. S. M atuszewski, Wplyw praktyki na brzmienie artykulów o naganie szlachectwa w przekazach Statutów Kazimierza Wielkiego, Zeszyty Naukowe UŁ 1971, ser. I, z. 83, s. 37-49.

${ }^{4}$ Najobszerniejszą i najbardziej wnikliwą jak dotąd pracą na temat procesu granicznego jest pochodząca z $1850 \mathrm{r}$. publikacja Stosława $Ł$ a gu n y, O prawie granicznem polskiem, [w:] Pisma Stoslawa Laguny, Warszawa 1915, s. 53-128.

s Stąd prawo do żądania rozgraniczenia lub odnowienia granic.

${ }^{6} \mathrm{R}$. K iers nowski, Znaki graniczne w dawnej Polsce, Archeologia Polski [Warszawa-Wroctaw] 1960 , t. V, z. 2, s. 257-289.

AKP III, Dzik., art. 150, s. 59.

${ }^{8}$ Wyjątkowo jedynie zainteresowaniem prawodawcy szlacheckiego cieszył się ten szczególny rodzaj procesu granicznego, który dolyczył granic między dobrami królewskimi i prywatnymi. 
4. $W$ podjętych przez nas badaniach nad problematyką graniczenia i postępowania granicznego zainteresowanie budzi znajdujące się w Statutach kazimierzowskich postanowienie zajmujące się problemem przebiegu granicy wyznaczanej nurtem rzeki czy strumienia i związanym $\mathrm{z}$ tym prawem do korzystania $z$ wody. Przepis dotyczy sytuacji, w której pojawia się konieczność rozstrzygnięcia o przebiegu granicy po tym, gdy doszlo do zmiany granicznego dotąd koryta rzeki czy strumienia.

4.1. Swoją ingerencję w tego rodzaju sprawy graniczne ustawodawca uzasadniał następująco: Crebra altricatione propter nostros subditos super limitibus in hereditatibus ipsorum distinguendis, graves questiones suscitantur, ex quibus expense augentur et labori nimio interdum subponuntur discordantes.

Ten interesujący nas przepis nie został pominięty $w$ żadnej $\mathrm{z}$ redakcji Statutów. Jednak zawarte $w$ nich rozstrzygnięcia różnią się $w$ sposób na tyle istotny, że trudno te zmiany wyjaśnić zwykłym błędem kopisty, technicznymi odmiennościami redakcyjnymi, czy też problemami wynikającymi $\mathrm{z}$ tłumaczenia. Są to po prostu różne co do treści postanowienia.

4.2. Na wstępie ustawodawca uznaje, iż rzeka czy potok stanowi granicę między nieruchomościami, wówczas gdy każdy z właścicieli sąsiadujących $\mathrm{z}$ akwenem ma prawo do brzegu, który leży po jego stronie $\mathrm{i}$ do zasobów wody: Et quia alvei fluviorum, ut plurimum, inter hereditates, profluunt et habentur, unde si que ville aut hereditates invicem conveniunt aliquo flumine vel rivulo mediante, ita, quod quelibet hereditas suam ripam teneat illius fluminis, ad ipsam protensam ${ }^{10}$. W tym zakresie nie dostrzegliśmy żadnych istotnych odmienności między poszczególnymi redakcjami. Postanowienie ma charakter generalnego ustalenia, do kogo należą brzegi granicznego cieku wodnego.

Przyjmując jednak taką zasadę, ustawodawca stanąl wobec problemu wynikającego z samej natury rzeki, mianowicie $\mathrm{z}$ faktu, że nie jest ona żywiołem stałym, ale ulegającym ciągłym przekształceniom.

4.2.1. Zmiany biegu rzeki tworzyły problemy natury prawnej; stanowiły - na to wskazuje ustawodawca - dokuczliwość zarówno dla właścicieli nadbrzeżnych nieruchomości, jak i tych wszystkich ${ }^{11}$, którzy mieli prawo

\footnotetext{
AKP II, Król., art. 2.

Ibidem.

${ }^{11}$ Kwestia zmiany biegu rzeki, zawsze aktualna, stanowila niezwykle istotny problem w XIII w. Wówczas intensyrikacja upraw i trzebież lasów, zwłaszcza na terenach podgórskich, negatywnie wpłyneła na układ hydrograficzny (przyspieszenie topnienia śniegów, a przez to wzrost fal powodziowych - o których informują już XIII-wieczne roczniki krakowskie); inną konsekwencją tej intensyfikacji było stopniowe wysychanie mniejszych strumieni i stepowienie, Encyklopedia historii gospodarczej, t. Il, red. A. Mączak, Warszawa 1981, rzeka (T. Lalik). Stąd zapewne szczególne zainteresowanie ustawodawcy tym problemem.
} 
dostępu do wody. Dlatego do Statutów wprowadzono przepis zajmujący się właśnie rozstrzygnięciem przebiegu granicy po zmianie biegu rzeki. Nie znamy niestety jego pierwotnego brzmienia.

Sprawa jest bardzo skomplikowana. Zmiana koryta rzeki może być wywolana zjawiskami naturalnymi, jak opady deszczu czy roztopy przyczyniające się do powstawania rozlewisk, erozją gruntu itd. Ale może być też wywolana zamierzoną działalnością człowieka. Czy w obu przypadkach rozstrzygnięcie dotyczące granicy biegnącej dotąd korytem rzeki winno być takie samo?

Przed ustawodawcą stały cztery możliwe do przyjęcia rozwiązania. Mógł uznać, że:

a) niezależnie od przyczyny zmiany biegu rzeki granicą pozostaje stare koryto;

b) granicę zawsze wyznacza bieg rzeki, a zatem zmienia się ona wraz z każdą (niezależnie od przyczyny) zmianą koryta;

W końcu zmianę przebiegu granicy można uzależnić od przyczyny wywołującej zmianę:

c) w przypadku zmian naturalnych stare koryto pozostaje granica, a gdy bieg rzeki zostanie zmieniony siłą ludzką, granicę będzie wyznaczać nowe koryto;

d) gdy bieg rzeki zmieniony zostanie siłami natury, wyznacza on nowy przebieg granicy; gdy zmiana spowodowana została celową działalnością ludzką, granica nie ulega zmianie.

Opowiadając się za jedną $\mathrm{z}$ tych moźliwości, ustawodawca musial dokonać wyboru między zapewnieniem trwałego i spokojnego, a mającego ogromne znaczenie gospodarcze dostępu do wody, a zasadą niedopuszczenia do zmian granic spowodowanych zmianą stanu faktycznego - fizycznym przemieszczeniem granicznego koryta, dokonanym bez dopełnienia jakiejkolwiek czynności prawnej.

Za rzecz zrozumiałą uznalibyśmy przyjęcie przez ustawodawcę jednolitego rozwiązania ustalającego jako obowiązujące jedno z przedstawionych wyżej rozstrzygnięć: a), b), c) lub d). Dziwić powinno zatem, gdyby pojawiły sie merytoryczne różnice między interesującymi nas przepisami w poszczególnych redakcjach. Czym bowiem mielibyśmy tłumaczyć odwołanie się w tej samej sprawie do odmiennych zasad?

\subsubsection{Jak jednak rzecz wygląda w rzeczywistości?}

- Według przekazu uznanego przez naukę za najpoprawniejszy, tj. Kodeksu Królewieckiego ${ }^{12}$, bieg granic po zmianie koryta rzeki przedstawia się następująco: ...quod si idem fluvius obmisso primevo alveo diverterit suum meatum sive defluxum per alia loca non ministerio hominis sed virtute propria,

${ }^{12}$ St. Roma n, Geneza Statutów..., s. 49, 116. 
tunc primus alveus, ubi ante fuit decursus aque, pro veris limitibus est reputandus $s^{13}$. Przepis nie budzi interpretacyjnych wątpliwości co do przyjętego rozstrzygnięcia. Ustawodawca postanawia, że zmiana biegu cieku wodnego spowodowana siłami przyrody nie wpływa na bieg granicy. Ogranicza jednak zakres swej decyzji przez zastrzeżenie non ministerio hominis. A tu już nie jesteśmy w stanie rozstrzygnąć, czy zmiana biegu rzeki wywolana działalnością ludzką ma w świetle omawianego przepisu - zdaniem prawodawcy - wplywać na zamianę linii granicznej, czy też powyższe zastrzeżenie ma tylko wskazać, że ustawodawca zainteresowany był jedynie zmianami biegu rzeki spowodowanymi naturalnymi przyczynami, nie rozstrzygając sytuacji odmiennej. Nie wiemy, czym spowodowany był taki właśnie kształt przepisu.

- W innych redakcjach Statutów ${ }^{14}$ znaleźć można odmienne rozwiązanie problemu. $\mathrm{O}$ ile tak samo, jak omówiony przepis regulują one sytuację, w której na skutek działania sił przyrody dochodzi do zmiany biegu wody, to równocześnie jednoznacznie wskazują na konsekwencje przesunięcia koryta rzeki na skutek działań człowieka: Secus autem dicimus, si fluxus fluminis a proprio meatu per reparationem hominis retrahatur, tunc etenim decursus fluminis pro terminis semper est habendus ${ }^{15}$.

Prawodawca uznaje, że świadoma działalność człowieka musi obejmować wszystkie skutki $\mathrm{z}$ nią związane $\mathrm{i}$ wobec tego granica własności ziemskiej przesuwa się wraz ze zmieniającym się biegiem rzeki.

Tak też rozstrzygnięto kwestię w redakcji polskiego przekładu Świętosława z Wojcieszyna: A yniako mowymi, bandzeli plynyenye rzeki oth wlostnego byegu przez oprawyenye czlowiecze odwroczono, to thedi wyacz byeeg rzeki za granicze zawzdi ymyaan ma bycz ${ }^{16}$. Racjonalność takiego postanowienia nie budzi wątpliwości: dostęp do wody, do pożytków z tym związanych, zachowany być winien na dotychczasowych zasadach, niezależnie od podejmowanych inwestycji. Zniechęca to do podejmowania prac na szkodę sąsiada: próba pozbawienia go dostępu do wody, przez przemieszczenie jej biegu, przyniesie jako skutek utratę części nieruchomości położonej między starym a nowym korytem.

Jeśli natomiast sąsiedzi chcieliby zachować dotychczasowy przebieg granicy, to nic nie stoi na przeszkodzie, by doprowadzili do tego w drodze odrębnej czynności prawnej. Takiej działalności - co oczywiste - Statuty nie wykluczają.

13 AKP II, Król., art. 2.

${ }^{14}$ AKP II, B IV, art. (26), s. 167; Oss. I, art 6, s. 58; P1., art. II, s. 114; Oss. III i Dział. III, art. 2, s. 210; Pet. II, art. 2, s. 339; W. II, art. 2, s. 401; AKP IV, Sier. I, art. 2, s. 12; Sier. II, art. 64, s. 59; B I i Oss. II, art. 2, s. 358; Stron. II, art. 2, s. 635.

is AKP II, B IV, art. (26), s. 167.

${ }^{16}$ AKP III, Swięt., art. 2, s. 249, 250; takie stanowisko prezentuje także S. L a gu n a (zob. wyżej, przyp. 4 , s. 65 ) 
Jednak $w$ Statutach odnajdujemy również rozwiązanie odmienne: ...si fluxus fluminis a proprio meatu per reparationem hominis retrahatur, tunc etenim decursus fluminis pro terminis non est habendus ${ }^{17}$.

Podobnie czytamy w większości polskich przekładów Statutów: I na to mowymy my, aczby tesz rzeka mocza czlowieczq gynqdy obroczona, a wszakosz pyrwsze brzegy, miedzy dzedzinami granicza czyniq ${ }^{18}$, jak i w tekście ruskim: A takoż berh reky koli budet czelowieczim czinenijem oboroczen, a wożdy perwejszii bereh - hranica ${ }^{19}$. Wobec przypadku zmiany koryta, do której przyczynil się człowiek, stosuje się - w myśl tych przekazów - tẹ samą regułe co przy zmianach naturalnych.

Jakakolwiek była przyczyna przyjęcia takiego rozstrzygnięcia, mieści się ono w ramach wyżej przedstawionych teoretycznych rozważan dotyczących sposobu rozwiązania problemu, jak przebiegać ma granica, gdy graniczna rzeka zmieni swój bieg.

Wydawać by się mogło, że wyżej wskazaliśmy wszystkie teoretycznie dopuszczalne możliwości uregulowania interesujących nas kwestii. $Z$ nich prawodawca - a właściwie redaktorzy poszczególnych wersji Statutów - nie wykorzystali tylko jednej, opisanej pod b), zakładającej, że granica na stale związana jest $\mathrm{z}$ czynnym korytem rzeki.

- Okazuje się jednak, że ustawodawca przewidział jeszcze jedno rozwiązanie powstałego problemu. Nie akceptując zmiany biegu rzeki granicznej, nie dopuszcza możliwości zmiany granicy i nakazuje jednocześnie przywrócenie stanu poprzedniego: A gdyby ona tho rzeka obroczyla sye gyndzye nye zlyudzkyego zrzqdzenya alye ssama swa mocza, thedy ono yey pyrzwe a stare lozyssko za pewne granycze ma bycz trzymano [...] a rzeka tha ysta ma bycz za sye na swe myeszcze obroczona ${ }^{20}$. Statuty nie wskazuja adresata tego nakazu, ale można przypuszczać, że skoro $w$ jednakowym stopniu chroni interesy obu sąsiadów, nie faworyzując żadnego, w jednakowym stopniu również nakłada na nich obowiązki. Trudno jednak, w większości przypadków, wyobrazić sobie wykonanie tego przepisu w praktyce. Nie wiemy też, co powodowalo twórcą tego nakazu.

4.2.3. Kolejną niezwykle istotną kwestią, która znalazła swoją regulację w omawianym przez nas artykule, jest prawo dostępu do wody ${ }^{21}$.

Regulą jest prawo mieszkańców obu sąsiadujących $z$ wodą nieruchomości do równego korzystania $\mathrm{z}$ rzeki. Ustawodawca nie tylko stwierdza, że natura nie może decydować o przebiegu granicy, ale wskazuje jednocześnie,

${ }^{17}$ AKP II, Jag., art. 2, s. 180; podobnie B II-gi, art. 3, s. 221.

${ }^{18}$ AK.P III, Dział. I-szy, art. 10, s. 184; a także Dzik., art. 10, s. 25; Strad., art. 11, s. 341.

19 Ruski przeklad z rękopisu moskiewskiego, art. 4, s. 61.

${ }^{20}$ AKP III, Dzik., art. 2, s. 83; a także Strad., art. 2, s. 450.

2: Patrz: Encyklopedia historii gospodarczej, t. II, woda. 
że natura nie decyduje także o prawie do pobierania pożytków z rzeki: Et ibidem in lacu illo de utraque villa homines inhabitantes faciant, licite suas piscaturas ${ }^{22}$.

I tu jednak możemy zastanawiać nad zamysłem ustawodawcy co do granic tego prawa: czy dotyczy ono samej rzeki: $A$ thamo $w$ rzecye oneem lovicz ribi sprawnye bandąn oboyey wszy lyvdze $e^{23}$, czy też tzw. niecieczy, czyli wody utrzymującej się $\mathrm{w}$ starym korycie, mimo iż głowny nurt wody przeniósł się gdzie indziej: ...a gdyby się stego vczynilo yezyoro, tedy lyudzie wssytczy obu wszy mayq $w$ nye $(m)$ lowicz $r y b y^{24}$. I w tej kwestii pojawiły sie różnie brzmiące przekazy postanowienia, choć samo rozstrzygnięcie - co do przyznania służebności - zawarto w obu.

Odrębnym zagadnieniem pozostaje kwestia, czy rozstrzygnięcie to stosowano również wobec sąsiadów, których nieruchomości nie stykają się z rzeką, ale którym przysługują związane $\mathrm{z}$ nią służebności.

5. Podsumowując rozważania na temat postępowania $w$ sprawie granicy wyznaczonej nurtem rzeki, należy zauważyć swoiste życie interesującego nas przepisu w poszczególnych redakcjach Statutów Kazimierza Wielkiego.

Potrzeby praktyki wymusily na ustawodawcy reakcje. Ustanowiona norma miała zapewne tę praktykę ułatwić, ujednolicić. Wydaje się jednak, że redaktorzy przekazów pozostają pod większym wpływem lokalnych zwyczajów - odmiennych od postanowienia zawartego $w$ pierwotnej wersji Statutów. Wskazuje to na niewielką siłę oddzialywania prawa stanowionego $w$ interesującej nas dziedzinie. To nie ono kształtuje praktykę, lecz odwrotnie: wykształcony w praktyce zwyczaj wpływa na treść kolejnych redakcji Statutów.

Ciekawą i godną bliższego badania sprawą jest także odbicie samego ustawodawstwa, funkcjonującego $w$ tak różnorodnej postaci $w$ zwierciadle praktyki sądowej ${ }^{25}$.

\footnotetext{
AKP II, Król., art. 2, s. 2.

${ }^{23}$ AKP III, Święt., art. 2, s. 233.

${ }^{24}$ AKP III, Strad., art. 2, s. 450.

${ }^{25} \mathrm{Wg}$ L. Lysiaka, znajomość statutów i ich wpływ na praktykę sądową była ,dość problematyczna", Statuty Kazimierza Wielkiego w Malopolskiej praktyce sq̨dowej $X V$ w., Studia Historyczne 1976, R. XIX, z. 1 (72), s. 25-39.
} 